\title{
Ciberespaço: horizontes e possibilidades
}

\section{Resumo}

Os avanços tecnológicos estão transformando a sociedade. A virtualização da realidade faz com que o ser humano passe a habitar o ciberespaço, um não-lugar formado por redes de computadores e informações interligadas. Este ambiente possibilita o "encontro" desterritorializado de tribos digitais que interagem predominantemente através de texto e avatares. Essa nova cultura, chamada de cibercultura, tem reflexos em todas as esferas da sociedade. A mudança paradigmática instaurada pelas tecnologias exige esforços para discutir e refletir sobre o contexto e sobre os novos horizontes e possibilidades que se apresentam para a educação.

\section{Abstract}

The technological advances are transforming the society. The virtuality of reality brings the human beings to cyberspace, a non-existent place formed by computer network and interconnected information. This environment makes it possible for no-territorial digital tribes to gather and interact through texts and avatars. This new culture, known as cyberculture, reflects in all spheres of society. The paradigmatic change brought about by technology requires effort to discuss and reflect upon the context and upon the new horizons and possibilities for education.

A sociedade está passando por um processo de virtualização mundial. $\mathrm{O}$ homem na era digital está perplexo, ädmirado e, mesmo, perdido na própria história. Esta situação social anuncia uma eminente transição-crísica paradigmática que requer "reinventar o futuro, abrir um novo horizonte de possibilidades" ${ }^{1}$, ou seja, de criatividade. Por isso, na atualidade, a humanidade está vivenciando uma mudança de paradigma que tem como um de seus símbolos o ciberespaço.

O conceito ciberespaço vem de cyberspace e surgiu no romance "Neuromancer" (1984) de William Gibson. O ciberespaço é um espaço comunicacional e simbólico, de virtualização da realidade, um mundo de interações virtuais desterritorializado que trabalha com uma nova temporalidade. O ciberespaço possui uma estrutura própria e códigos que só fazem sentido neste mundo digital. Gibson define ciberespaço como: "uma alucinação consensual, que pode ser experimentada através de softwares especiais", um não-lugar, não-territorial, composto de redes de computadores interligados, no qual informações circulam das mais variadas formas. Ted Nelson considera o ciberespaço como um gigantesco hipertexto planetário, ou seja, um sistema interativo aberto para trocas e diversas conexões com outros hipertextos.

Gutenberg expandiu mundialmente a leitura; a criação da Xerox permitiu a editoração eletrônica; a eletrônica-computacional permitiu a autoria em redes.

A facilidade de manipulação da Interface Gráfica, determinada pela disponibilização de ícones (que permitem o acesso a programas, arquivos, etc.) na tela do computador, faz com que muitas pessoas desenvolvam uma relação mágica com a máquina, que se transformou em um mito da era pós-moderna. Uma das explicações para essa mistificação da máquina é a perda do mecanismo de compreensão do que está

\footnotetext{
* Doutoranda em Educação e Mestre em Didática pela Faculdade de Educação da Universidade de São Paulo. Professora do curso de Pedagogia das Faculdades Integradas "Campos Salles" e Instructional Designer do Instituto Presbiteriano Mackenzie de São Paulo.

${ }^{1}$ B. SANTOS, Pela mão de Alice: o social e o político na pós-modernidade. Cortez, 1997, p. 322.
} 
por trás desta interface gráfica amigável. A mesma aplicação de Interface Gráfica amigável possibilitou a popularização da Internet e utilização dos serviços disponíveis nesta Rede Comunicacional - determinada pela velocidade, mutabilidade, interação e reciprocidade. O ciberespaço, então, trouxe uma nova concepção de realidade, tempo, espaço, relacionamento, que, além de tudo, permitiu a libertação do imaginário pelo anonimato pessoal (tanto do ponto de vista lingüístico da não-identificação do indivíduo, quanto do ponto de vista corporal).

Esta revolução, anunciada por Alvin Tofler como a "Terceira Onda", está proporcionando a intensificação das interações globais e desterritorialização das relações sociais. Boaventura, todavia, alerta para o fato de que "assiste-se a um desabrochar de novas identidades regionais e locais alicerçadas numa revalorização do direito às raízes (em contraposição com o direito à escolha). [...] Contudo, assenta sempre na idéia de território, seja ele imaginário ou simbólico, real ou hiper-real." 2 A territorialidade digital assume a metáfora de porto seguro, onde o ser humano encontra seus pares, membros de grupos que podem nem se conhecer pessoalmente, mas que assumem compromissos conjuntos e desenvolvem laços de amizade e relacionamento a distância.

A formação e transformação dos grupos sociais, oriunda da organização e adaptação do cotidiano vivencial através de sistemas e práticas simbólicas mediáticas organizacionais e educativas (internas ao grupo e intergrupais), assume uma nova configuração na pós-modernidade: tribos ciberespaciais. As tribos que interagem através do ciberespaço, como os grupos sociais, se diferenciam pela linguagem, pelos valores, pelas crenças, pelos hábitos e mesmo pelos conhecimentos e ritos. Para a Antropologia, os ritos são organizadores do espaço temporal de uma determinada tribo (pelas práticas simbólicas inerentes à mesma), contribuindo para efetivar a identidade grupal. No ciberespaço, os ritos seriam relativos aos Avatares e outros ícones e códigos próprios de cada comunidade virtual.

As comunidades (ou tribos) digitais utilizam vários serviços oferecidos pela Internet para comunicação e interação. $\mathrm{O}$ e-mail e as Listas de Discussão ${ }^{3}$ são formas de comunicação assíncronas, que dispensam a participação simultânea dos usuários. O IRC (Internet Relay Chat), mais conhecido como Chat ou Bate-papo é síncrono, ou seja, permite a troca de informações entre os participantes em tempo real. Em e-mails, listas de discussão e salas de bate-papo são utilizados, muitas vezes, Emoticons (Smiles): ícones, formados por caracteres de texto para expressar sentimentos ${ }^{4}$. Os membros das tribos digitais também utilizam Avatares para sua representação virtual. A palavra Avatar vem da Mitologia Oriental, e simboliza uma pessoa que veio à Terra para promover a evolução da humanidade. No ciberespaço, Avatar é uma representação gráfica de um corpo (na maioria das vezes de forma humana) que reflete as ações do usuário (expressões faciais, troca de objetos etc.). Uma outra forma de interação é propiciada pela Videoconferência, que permite, além de conversa pelo teclado, a transferência de arquivos, imagens, visualização do interlocutor (através de webcam) e conversa utilizando o microfone do computador.

O contato via texto, predominante na esfera digital, permite a percepção das idéias e personalidades dos indivíduos desvinculados da voz e da aparência física, gerando uma exacerbação da linguagem e da imaginação. Entra-se em contato com a personalidade (real ou imaginária) do indivíduo e, na maioria das vezes, não se chega a estabelecer um contato com a aparência física do interlocutor. O ciberespaço permite o "encontro", a discussão de idéias, mesmo que não seja físico-corpórea. A mediação lingüística e codifi-

\footnotetext{
${ }^{2}$ Idem, p. 22

${ }^{3}$ Lista de Discussão ou Mailing List - representa a troca de e-mails sobre um determinado assunto, constituindo, inclusive, uma forma de tribalização.

${ }^{4}$ Exemplos de emoticons:

:-) Feliz :-D Sorriso : :-( Triste
} 
cada estabelecida pela tribo digital assume, então, uma dimensão hermética no ciberespaço, pois, como coloca Morin,

... a mensagem 'muitos beijos' em tibetano é ruído para os meus ouvidos e todavia representa informação tibetana. (...) Vemos, portanto, muito bem que a informação e a redundância se confundem em ruídos logo que deixa de haver código comum entre receptor e emissor, visto que a chave da sua distinção reside neste código. ${ }^{5}$

O código, mais uma vez, pode ser relacionado ao ritual, aos procedimentos de conexão com a Rede, e, conseqüentemente, com o acesso ao ciberespaço. Assim, o "ciberespaço é onde se realizam ritos de passagem do espaço físico e analógico ao espaço digital sem fronteiras, do corpo átomo ao corpo bit. [...]; de um social marcado pelo indivíduo autônomo e isolado ao coletivo tribal e digital." ${ }^{6}$ Rito este que possibilita uma experiência de insight, acompanhada do fascínio da máquina empreendedora - que, na realidade, não é um ser pensante, e sim uma cumpridora de rotinas hierarquizadas.

Em relação ao caráter mágico do ciberespaço, pode-se salientar, ainda, a onipresença, o realtime e a falta de espaço físico determinado. A desmaterialização espacial e tempo instantâneo do ciberespaço seriam, então, provenientes da própria sociedade contemporânea, pois "O ciberespaço é, em conseqüência, uma casa da imaginação, o lugar onde se encontram racionalidade tecnológica, vitalismo social e pensamento mágico.”

A partir do panorama traçado anteriormente, pode-se discutir o conceito de cultura do ciberespaço, denominada, por Pierre Lévy, como Cibercultura. A cibercultura é caracterizada pela "universalidade sem totalidade", ou seja, pela possibilidade de formação de uma comunidade mundial a partir do processo de globalização e avanço tecnológico, mesmo que essa comunidade possua conflitos e não seja igualitária - o mais importante são as interações sociais que podem ser estabelecidas através das novas tecnologias. A cibercultura se traduz pelos excessos: de informação, de comunicação, de tecnologia.

Pierre Levy, em seu livro "A Inteligência Coletiva. Por uma Antropologia do Ciberespaço", ressalta que o ciberespaço instaurou um novo espaço antropológico, no qual se efetuaria o que ele denomina Inteligência Coletiva - a qual teria uma distribuição direcional total, com valorização abrangente em tempo real, conduzindo às efetivas competências. De forma complementar, Eduardo Duarte coloca que o ciberespaço se apresenta como uma hiper-realidade, e que a cibercultura abarca "um caldeirão fervente de expressões culturais que aglutinam-se numa proposta global de identidade própria."

Estes conceitos convergem para uma única pergunta: qual é o papel da educação nesta sociedade complexa, simbiótica, simbólica, tecnológica, que toma a velocidade e diversidade de informações como ícones evolutivos?

No campo paradigmático-educacional podese encontrar duas vertentes, apresentadas a seguir numa tabela comparativa:

\footnotetext{
${ }^{5}$ E. MORIN, O método - 1. A natureza da natureza. 2. ed. Portugal: Publicações Europa-América, 1977, p. 317

${ }^{6}$ A . LEMOS, As estruturas antropológicas do ciberespaço, (18/11/97).

${ }^{7}$ Idem.

${ }^{8}$ E. DUARTE, Um novo caos para um novo universo, (18/11/97).
} 


\begin{tabular}{|c|c|c|}
\hline & Paradigma Patente & Paradigma Emergente \\
\hline Posição em relação à(ao) & Professor (como é) & Como deveria ser... \\
\hline Professor & Detentor e transmissor do saber & Orientador do estudo \\
\hline Aluno & Receptor passivo & $\begin{array}{l}\text { Agente de aprendizagem } \\
\text { autônomo }\end{array}$ \\
\hline Sala de Aula & Ambiente de recepção do saber & $\begin{array}{l}\text { Ambiente de construção e troca } \\
\text { de conhecimentos }\end{array}$ \\
\hline Experiência & $\begin{array}{l}\text { Transmitida hierarquicamente } \\
\text { do professor para o aluno }\end{array}$ & $\begin{array}{l}\text { Troca mútua entre os membros } \\
\text { do grupo (incluindo o professor } \\
\text { como integrante) }\end{array}$ \\
\hline Aprendizado e Estudo & Obrigatório, punitivo, terrorista & $\begin{array}{l}\text { Aprendizado conjunto, prazeroso, } \\
\text { que conduz ao crescimento }\end{array}$ \\
\hline Conteúdos Curriculares & $\begin{array}{l}\text { Fixos, numa estrutura de } \\
\text { formatação rígida e restrita }\end{array}$ & $\begin{array}{l}\text { Abertos, numa estruturação } \\
\text { flexível de múltiplos caminhos }\end{array}$ \\
\hline $\begin{array}{l}\text { Mídia Tecnológica (NTC - } \\
\text { Novas Tecnologias de } \\
\text { Comunicação) }\end{array}$ & $\begin{array}{l}\text { Utilização esporádica para } \\
\text { chamar a atenção sobre certo } \\
\text { tema, tornando-o agradável }\end{array}$ & $\begin{array}{l}\text { Instrumento incorporado à sala } \\
\text { de aula, com várias mídias } \\
\text { integradas simultaneamente }\end{array}$ \\
\hline $\begin{array}{l}\text { Tecnologia - Informática } \\
\text { educacional }\end{array}$ & $\begin{array}{l}\text { Mito do medo da substituição } \\
\text { do professor pela máquina } \\
\text { instrucional }\end{array}$ & $\begin{array}{l}\text { Artefato para estímulo da } \\
\text { aprendizagem }\end{array}$ \\
\hline $\begin{array}{l}\text { Manipulação das NTCs - } \\
\text { Novas Tecnologias de } \\
\text { Comunicação }\end{array}$ & $\begin{array}{l}\text { Somente pelo professor, o qual } \\
\text { estrutura sua aula com } \\
\text { antecedência }\end{array}$ & $\begin{array}{l}\text { Manipulação conjunta por parte } \\
\text { de professores e alunos, que } \\
\text { trocam conhecimentos e idéias }\end{array}$ \\
\hline
\end{tabular}

No paradigma emergente, o erro como algo ruim e negativo seria superado e passaria a ser encarado como campo de possibilidades de acerto; não haveria mais o pânico do professor onipotente (que sabe tudo sobre todos os assuntos), mas sim um educador bem preparado e apaixonado pela busca de conhecimentos junto com os alunos, formando uma equipe de pesquisadores. Esse tipo de trabalho está relacionado à aprendizagem cooperativa:

"Aprendizagem cooperativa é o uso instrutivo de pequenos grupos de modo que estudantes trabalhem juntos para alcançar metas compartilhadas. Nos grupos de aprendizagem cooperativa são dadas suas responsabilidades aos estudantes: aprender o material partilhado e ter certeza de que todos os outros membros do grupo o fazem igualmente. Aprendizagem cooperativa pode ser usada para ensinar um conteúdo específico (grupos formais de aprendizagem cooperativa), assegurar um processamento cognitivo ativo das informações durante as conferências (grupos infor- mais de aprendizagem cooperativa), e prover apoio a longo prazo e auxílio para o progresso acadêmico (cooperativa de grupos de base). Qualquer tarefa em qualquer currículo para qualquer idade estudantil pode ser estruturada cooperativamente, se o professor tem o treinamento adequado".

A proposta da aprendizagem cooperativa está vinculada e permeada pela clareza das metas e objetivos que o grupo pretende alcançar com o trabalho conjunto. Todos conseguem visualizar seu papel e contribuição para com a equipe, bem como o enriquecimento e produtividade decorrentes desta modalidade de trabalho educacional. Do ponto de vista das individualidades, é necessário ressaltar que, numa abordagem cooperativa, os jovens têm a oportunidade de discutir idéias e posicionamentos, abrindo um espaço para o crescimento e prática da autonomia, bem como da interação coletiva.

Para trabalhar com novos horizontes didáticos, é necessário rediscutir o significado original

${ }^{9}$ Cooperative Learning and Conflict Resolution. New Horizons for Learning, 1997/1998. Disponível em: < http://www.newhorizons,org/trm_johnson.html> Acesso em 10 nov. 1998. 
da palavra Método: Caminho - "O caminho que pode ser seguido não é o Caminho Perfeito. (...) O que pode ser seguido é o velho, o que está na memória, o produto do condicionamento e de velhos hábitos. (...) O caminho que não pode ser seguido é o novo, o espontâneo, o que de instante a instante se revela"10 De maneira análoga, o melhor método (condizente com a filosofia e práticas apresentadas pelo paradigma emergente) seria o que ainda não foi desenvolvido, que está em um contínuo estado de criação/reformulação pela busca de caminhos não percorridos outrora.

Outro ponto a ser destacado é a informação:

"Quanto mais a comunicação se desenvolve, mais a informação se multiplica, mais se gasta e se dispersa aleatoriamente em todos os horizontes, à procura dum receptor esperado, e muitas vezes desconhecido." ${ }^{11}$

Portanto, não há interação sem desordem (desigualdades, turbulências, agitações), não há ordem nem organização sem interações - os conceitos de ordem e organizações estão interligados assim, quem pretende formar, almeja transformar. Utilizando a metáfora de "página", pode-se dizer que a mudança do professor seria no sentido de...

Em vez de um texto localizado, fixado em suporte de celulose, no lugar de um pequeno território com um autor proprietário, um início, um fim, margens formando fronteiras, confrontei-me com um documento dinâmico, aberto, ubiqüitário, que me reenviava a um corpus praticamente infinito. $\mathrm{O}$ mesmo texto tinha outra natureza. Falamos de 'página' em ambos os casos, mas a primeira página é um pagus, um campo demarcado, apropriado, semeado com signos enraizados, o outro é uma unidade de fluxo, submetida às restrições das taxas de transmissão das redes. Mesmo quie se refira a artigos ou livros, a primeira página é fisicamente fechada. A segunda, em contrapartida, nos conecta técnica e imediatamente a páginas de outros documentos, dispersas em todas as partes do planeta, que remetem por sua vez, indefinidamente, a outras páginas, a outras gotas do mesmo oceano mundial de signos flutuantes. (Lévy, 1999, p.159)

Retomando a questão da Internet, pode-se dizer que a Rede Comunicacional permite uma infinidade de combinações através dos links (Elos), mas também deve-se atentar para o ciberespaço, para a cultura que é explicitada neste veículo (a quem serve, atende, como interage etc.). A linguagem computacional também está efetuando modificações sócio-antropológicas visíveis e irreversíveis no que tange à comunicação de informações (troca, criação, desenvolvimento, interatividade etc.), mas a máquina artificial não possui generatividade própria, ou seja, não é capaz de regenerar-se, reproduzir-se, reparar-se e mesmo de auto-organizar-se, pois seu controle é exterior (seguindo um modelo preestabelecido); também, ainda, não é criativa, inventiva (falta-lhe o que Morin chama de maquinante), o que acaba caracterizando-a como instrumento, apêndice do ser antropossocial.

Conclui-se, assim, que o progresso do conhecimento está vinculado à redistribuição da redundância, da informação e do ruído. Contudo, deve-se tomar cuidado para não passar do "culto à palaura" para o culto à hipermídia, ao hipertexto - é preciso o desenvolvimento da criticidade. Ainda, é primordial ter cuidado para não supervalorizar o mito do Mundo Virtual, porque, caso contrário, corre-se o risco de, paulatinamente, se afastar do mundo real fenomênico num processo de crescente alienação e de atribuições endeusadoras à Rede - usando a metáfora da vida através da tela (virtual) como fuga da realidade patente.

E, no que concerne a Informação, é importante vislumbrar que "Toda a informação degenerada pode ser regenerada se encontrar uma cabeça decifradora e uma matriz generativa." ${ }^{12} \mathrm{O}$ professor

\footnotetext{
${ }^{10}$ TSÉ, Lao. O livro do caminho perfeito - Tao Té Ching. São Paulo: Pensamento, 1991, p. 2

${ }^{11}$ MORIN, E. O método-1. A natureza da natureza. 2. ed. Portugal: Publicações Europa-América, 1977, p. 306.

${ }^{12}$ Ibid., p. 314
} 
quer um produto semi-acabado - seguindo um trabalho de linha positivista, quando na verdade a escola deveria realizar essa atividade regenerativa/generativa. Aliás, o trabalho com a informática permite, de várias formas, a percepção concreta deste enunciado, como, por exemplo, através da analogia com a editoração de texto. Não se deve esquecer que a Educação é mais do que instrução, é uma nova organizacionalidade alicerçada em práticas sócio-educativas. Portanto, os pesquisadores e membros da universidade precisam acordar e sair deste isolamento, ou melhor, da "Torre de Marfim", como é denominada por Boaventura, e partir para a resolução dos problemas do mundo contemporâneo, pois, com certeza, tem muito a contribuir para a melhoria da Humanidade.
Finalmente, é preciso atentar para o fato de que existe um vínculo entre as formas de conhecimento e as práticas sociais, deste modo, há uma inter-relação entre as transformações nas maneiras de conhecer com as transformações na organização da sociedade. Cabe à instituição escolar estar vigilante para essas mudanças estruturais, para não correr o risco de ficar definitivamente defasada e desinteressante, formando indivíduos sem qualquer espécie de iniciativa, criatividade e autonomia.

"o problema crucial é o do princípio organizador do conhecimento, e que o que é vital hoje não é apenas aprender, não é apenas reaprender, não é apenas desaprender, mas sim reorganizar o nosso sistema mental para reaprender a aprender. ${ }^{13}$

\section{REFERÊNCIAS BIBLIOGRÁFICAS}

GUIA da Internet.br "Contatos Cibernéticos: Redes de Micros e de Almas." Internet.br, Rio de Janeiro, Ano I, n. 5, p. 32-43, out. 1996.

LÉVY, Pierre. A inteligência coletiva: por uma antropologia do ciberespaço. São Paulo: Loyola, 1998.

. As tecnologias da inteligência: o futuro do pensamento na era da informática. Rio de Janeiro: Editora 34, 1997.

. Cibercultura. Trad. Carlos Irineu da Costa. São Paulo: Editora 34, 1999. (Coleção TRANS)

. O que é o virtual? Rio de Janeiro: Editora 34, 1996.

MORIN, Edgar. O método - 1. A natureza da natureza. 2.ed. Portugal: Publicações Europa-América, 1977. 363p. (Biblioteca Universitária, 28)

PEDREIRA, Jacqueline Gomes. Avatar, você ainda vai ter o seu. Internet.br, Rio de Janeiro, Ano I, n. 5, p. 44-49, out. 1996, PEDROSA, Monica Miglio. Cabeças da rede - entendendo o comportamento humano na Internet. Internet.br, Rio de Janeiro, Ano I, n.12, p. 44-49, maio 1997.

1997.

. Contatos imediatos: comportamento no mundo digital. Internet.br, Rio de Janeiro, Ano II, n. 17, p. 62-67, out.

PORTO, Maria do Rosário Silveira. Complexidade social e cultura escolar. 1997. Palestra proferida no Curso de Pós Graduação em Educação da Faculdade de Educação da Universidade de São Paulo. (mimeografado)

RAMAL, A. Educação.BR: um novo paradigma em educação. Internet.br, Rio de Janeiro, Ano I, n. 12, p. 80-81, mai. 1997,

SANTOS, Boaventura de Sousa. Cinco desafios à imaginação sociológica. In: Pela mão de Alice: o social e o político na pósmodernidade. 3. ed. São Paulo: Cortez, 1997, Cap. 1, p. 17-22.

- Da idéia de universidade à universidade de idéias. In: Pela mão de Alice: o social e o político na pós-modernidade. 3. ed. São Paulo: Cortez, 1997. Cap. 8, p. 187-233.

. O Norte, o Sul e a utopia In: Pela mão de Alice: o social e o político na pós-modernidade. 3. ed. São Paulo: Cortez, 1997. Cap. 10,p. 281-348.

TEIXEIRA, Maria Cecília Sanchez. Cultura escolar: os ritos enquanto práticas simbólicas organizadoras do espaço-tempo do grupo. 1997. Palestra proferida no Curso de Pós-Graduação em Educação da Universidade Federal Fluminense. (mimeografado).

TSÉ, Lao. O livro do caminho perfeito (Tao Té Ching). 7.ed.,Trad. e adap., prefácio e comentários: Murilo Nunes de Azevedo. São Paulo: Pensamento, 1991, 152 p.

${ }^{13}$ MORIN, E. O método - 1. A natureza da natureza. 2. ed. Portugal: Publicações Europa-América, 1977, p. 24 
VILLELA, Fernando. CiberCultura.BR . Internet.br. Rio de Janeiro, Ano I, n. 7, p. 46-51, dez. 1996.

CiberCultura.BR - Tomo II. Internet.br. Rio de Janeiro, Ano I, n. 8, p. 22-25, jan. 1997.

CiberCultura.BR - Tomo III. Internet.br, Rio de Janeiro: Ediouro, Ano I, n. 9, p. 22-25, fev. 1997.

. ExpansivaMENTE: consciência virtual. Internet.br. Rio de Janeiro, Ano I, n.10, , p. 32-41, mar. 1997.

BIBLIOGRAFIA TELEMÁTICA

DUARTE, Eduardo. "Um Novo Caos para Um Novo Universo". Disponível em: <http://www.cac.ufpe.br/libvirt/artigos/ed9701.htm> Acesso em 18 nov. 1997.

LEMOS, André. "As estruturas antropológicas do ciberespaço", Cyberpesquisa, Disponível em: < http://www.facom.ufba.br/pesq/cyber/artigos/estrey1.html> Acesso em 18 nov. 1997.

MANTA, André \& SENA, L.H. "As afinidades virtuais. A sociedade no videopapo" Disponível em: <http://www.facom.ufba.br/pesq/cyber/artigos/videopap.html> . Acesso em 18 nov. 1997.

MARASCO, Thomas G, "Diário de Bordo de Um Navegador Solitário", Disponível em: < http://www.quattro.com.br/passage/diario.htm> Acesso em 19 nov. 1997. 